\title{
Ultrastructure alterations of retinal photoreceptors of the black rat, Rattus rattus exposed to certain heavy metals
}

\author{
Elsayed F. A. El-Dawi ${ }^{1}$ and Naima I. Naguib ${ }^{2}$ \\ 1-Department of Zoology, Faculty of Science, Ain Shams University, Cairo, Egypt \\ 2-Health Radiation Research Department, National Centre for Radiation Research and \\ Technology, Atomic Energy Authority, Cairo, Egypt
}

\begin{abstract}
Aim of work: This study was designed to investigate the impact of lead and cadmium on the retinal photoreceptors of rats.

Material \&Methods: Adult black rats, Rattus rattus, were selected and divided into control and exposed groups. The exposed group was housed in industrial car batteries room containing fumes of lead and cadmium. The retina prepared for scanning and transmission electron microscopy.

Results: The scanning electron microscopy revealed different lead-cadmium changes represented by gradual increasing in spaces between segments of the photoreceptors, associated with swelling of their inner segments and accompanied with rupture, degeneration and decreased numbers of some rods and cones in the outer segments. Disorganization, shortening, a decrease in number of the photoreceptors and a great deformity were the characteristic changes after prolonged exposure to the heavy metals. The aforementioned damages of the photoreceptors were confirmed at the ultrastructural level using transmission electron microscope in the form of progressive disorganization, shortening, swelling, widening of the intradiscal spaces, vacuolization and degeneration of the lamellae of the outer segments (OS), followed by the damage of mitochondria of the inner segments(IS). Excessive penetration of the processes of the pigmented epithelium (PE) filled with pigments of different shapes and sizes between the damaged segments were noted. These pathological changes were considered the first symptoms in the retinal toxicity.
\end{abstract}

Conclusion: The present results are alarming and call for further investigations to elucidate the impact of exposure to these heavy metals for longer periods on the rat vision and eye structure.

Key words: Photoreceptors, SEM, TEM, Heavy metals, Rats

\section{Introduction}

Pollution is still the main problem of the world. Today, as a result of modernization and construction of different manufactories of batteries, oil, refining and painting industries, the pollutants became widely distributed in the air, soil and water. These pollutants affect all living organisms, including man.

Lead and cadmium are among the most common heavy metal pollutants, which contribute to environmental pollution because of their worldwide natural presence in batteries, coal, mineral, oils and in several chemical industries (Gerhardsson and Skerfving, 1996). The hazards of these two metals are not only due to their high toxicity, but also due to the low rate of elimination from the consumers' body, and often unchanged for long periods (Allen, 1995).

In many investigations, of heavy metal impacts, fishes and rats have been used as 
convenient models for studies that can't be performed on humans. These studies suggest that heavy metals may be etiologically involved in various pathological effects including most body organs (Bano and Hasan, 1990; Pundir and Saxena, 1992; Lockitch, 1993; ElDawi and Elbadry, 2001; El-Dawi, 2004; Elgamal and Hassanien, 2007.).

The eyes are considered as a potential sensitive site of pollutants toxicity, as they are exposed directly and continuously to the surrounding environment. Moreover, the histological structure of the animal eyes is greatly similar to that of humans (Andrew and Hickman, 1974; Ali and Klyue, 1985), and consequently, it is easier to manipulate the fish and rat eyes rather than the human eyes to evaluate the chemicalinduced histopathological alterations (Burnside and Ackland, 1983; Kirsch et al., 1989 ; Shimoda and Kalo, 1999; Yargicoglu et al., 1999; El-Dawi and Elbadry, 2001; El-Dawi, 2004; Roozbehi, 2007;Mulak et al.,2008). However, the reports concerned with the impact of the pollutants on eye retinal structure are sporadic, scarce or nearly neglected in rats and human.

In the majority of the investigations, a single pollutant was used, but this is not the case in nature, where more than one contaminant is usually present. These contaminants do not act individually on eyes, but they interact with each other in a way that may result in modifying their toxicological effects. Thus, the present investigation is focused on the scanning and transmission ultrastructural alterations of the photoreceptors of the black rat, Rattus rattus experimentally exposed to fumes of lead and cadmium in the car batteries factories, hoping that this study may provide us a fair knowledge about the morphological alterations of the photoreceptors and also may represent a preliminary investigation for our further detailed studies on other retinal layers.

\section{Material and methods}

\section{Chemical analysis of the car battery:}

According to the reports of WHO (1984) and the trace metal analysis method of APHA (1985), the chemical components of the car batteries are lead, sulphoric acid, cadmium and nickel. The air samples from different localities in Cairo and Giza cities were collected monthly from different departments (lead and cadmium smelter departments) of the car batteries manufactories and the measurements of the lead and cadmium particles and fumes were calculated (Elgamal and Hassanien, 2007; Simeonov and Hassanien, 2009). The data were represented in table (1).

\section{Experimental animals:}

Sixty adult black rats, Rattus rattus, (Order: Rodentia, Family : Muridae) (aging 6 months and weighing $100 \pm 20 \mathrm{~g}$ ) supplemented from the Research and Training Center on Vector Diseases- Ain Shams University. The rats were then acclimatized in environmentally controlled conditions with day light cycle, and had free access to commercial rodent pellets and water ad libitum. After two weeks, 42 of the healthy rats were selected and divided randomly into 2 groups (control and exposed groups) each group with 21 rats.

The control group was housed in healthy condition laboratory room, whereas the exposed group was housed in industrializing car batteries room containing fumes of lead and cadmium.

Table 1: Mean concentration of lead and cadmium particulate and fumes in the lead smelter and cadmium smelter departments. Values given are \pm SE

\begin{tabular}{|c|c|c|c|}
\hline Department & \multicolumn{3}{|c|}{ Concentration $\mu \mathrm{g} / \mathrm{m}^{3}$} \\
\hline & Particulate & Fumes & Total \\
\hline Lead smelter & $0.61 \pm 0.083$ & $2.25 \pm 0.25$ & 2.86 \\
\hline Cadmium smelter & $608.85 \pm 68.96$ & $1914.75 \pm 342$ & 2523.60 \\
\hline
\end{tabular}




\section{Dissection:}

At age 8 (after 2 months of exposure), 10 (after 4 months of exposure) and 12 (after 4 months of exposure) months, seven rats were randomly selected from each group and sacrificed by decapitation. The eyes of each rat were carefully and immediately enucleated and cleaned of extraneous tissue. Each eye was hemisected with a razor blade and the posterior cup was taken out, and the lens was removed under a dissecting microscope. The retina was then dissected carefully by using fine forceps and iris scissors and prepared for scanning and transmission electron microscopy.

\section{Scanning electron microscopy (SEM):}

The dissected retinal samples were cut into small pieces (pigmented epithelial layer of some retinal pieces were removed) and fixed in cold $2 \%$ glutaraldehyde- $2 \%$ paraformaldehyde in $0.1 \mathrm{M}$ phosphate buffer, $\mathrm{pH} 7.4$ at room temperature for 60 minutes. They were then washed twice in buffered sucrose $(0.1 \mathrm{M}$ phosphate buffer, $5 \%$ sucrose solution) for 5 minutes. The tissues were post-fixed in $2 \%$ osmium tetraoxide $\left(\mathrm{OsO}_{4}\right)$ with $2 \%$ phosphate buffer for 2 hours at $4^{\circ} \mathrm{C}$. After fixation, the tissues were dehydrated in upgraded series of ethanol. They were further dehydrated in absolute ethanol: acetone (1:1) solution for further 30 minutes, then in absolute acetone for 3 - 10 minutes. The tissues were dried in $\mathrm{CO}_{2}$ drying apparatus (Critical-Point Dryer, CPD 030) and mounted on stubs, then coated with gold in Sputter Coater (SCD 005). They were examined and photographed using a Philips Scanning Electron Microscope XL30 at the Department of Anatomy, Faculty of Medicine, Ain Shams University.

\section{Transmission electron microscopy (TEM):}

The dissected retinal samples were cut radially into small pieces and fixed in cold $\left(4^{\circ} \mathrm{C}\right) 2 \%$ glutaraldehyde in $0.2 \mathrm{M}$ phosphate buffer ( $\mathrm{pH}$ 7.4) for 2 hours, according to Millonig (1964) and postfixed $\left(2\right.$ hours at $\left.4^{\circ} \mathrm{C}\right)$ in $\mathrm{OsO}_{4}$ for electron microscopy. The samples were then dehydrated, treated with propylene oxide, infiltrated and embedded in Epon 812. Semi-thin sections were cut with the RMCMT7 ultra-microtome and stained with toluidine blue. Ultra-thin sections (silvery) were cut, using a diamond knife and stained with uranyl acetate and lead citrate. The sections were then examined using a Joel 1200 Ex II transmission electron microscope at the Department of Zoology, Faculty of Science, Ain Shams University

\section{Results}

\section{Control Group:}

The examination of the retina of the black rats, Rattus rattus, by SEM revealed that the photoreceptor layer $(\mathrm{PhR})$ was formed of many cones (C) and a small number of rods $(\mathrm{R})$. Each one was well differentiated into an outer segment (OS) and an inner segment (IS). Parallel Muller fibers extend along the IS to the OS. The pigmented epithelial cells (PR) are the outermost layer coating the photoreceptors and their processes interdigitate within the outermost part of the OS of rods and cones (Figs. $1 \& 2)$.

Transmission electron microscopy (TEM) revealed that the OS of rods had relatively uniform diameters, while those of cones were broader at the base. The OS of both rods and cones were made up of stacks of disc-like membranes (lamellae), formed by extensive and contact folding of the photoreceptor plasma membranes and contained in between them fine spaces (intradiscal space). On the other hand, the IS were filled with mitochondria (Fig.3) 

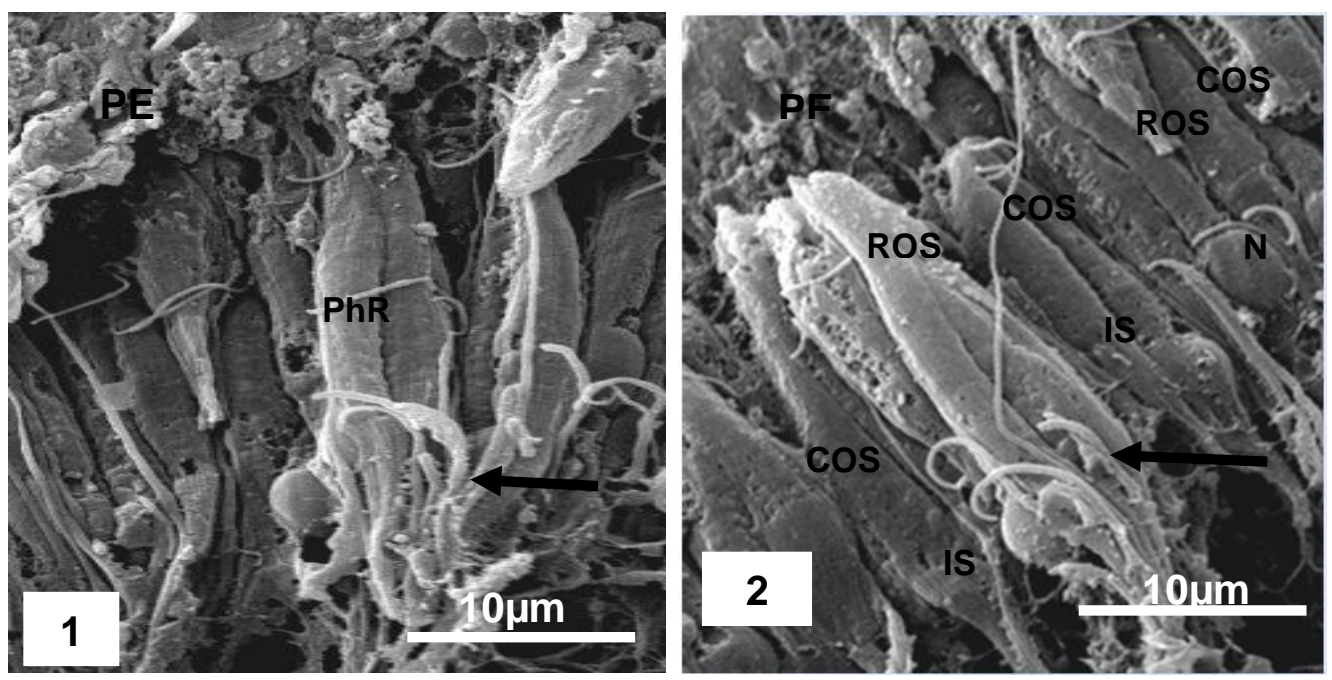

Fig. 1 : Scanning electron photomicrograph of the control rat, Rattus rattus, showing the normal structure of photoreceptors (PhR) and pigmented epithelium (PE). Notice many fibers of Muller cells (arrow).

Fig. 2: Scanning electron photomicrograph of the control rat, Rattus rattus, showing the normal structure of photoreceptors and decapitated pigmented epithelium. Notice the cones outer segment (COS) and rods outer segments (ROS) and the inner segments (IS). Notice also the pigmented epithelium (PE) and nucleus $(\mathrm{N})$ many fibers of Muller cells (arrow).

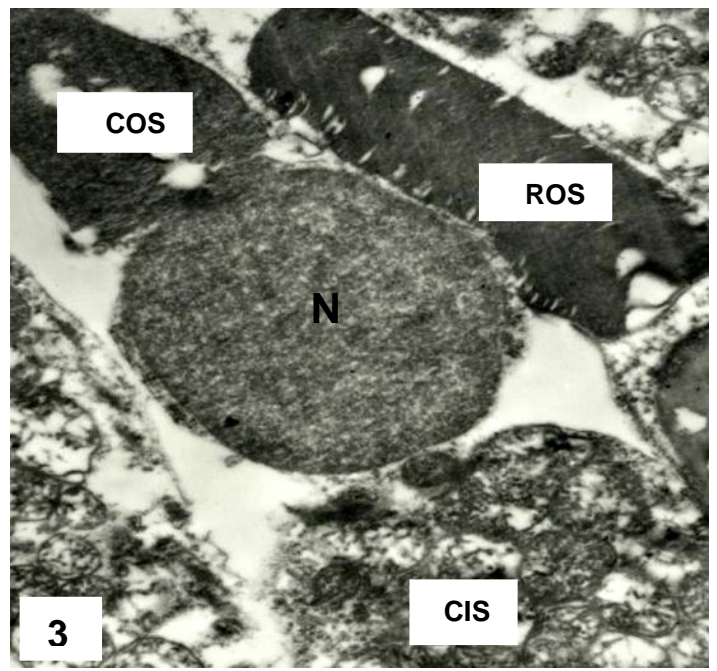

Fig. 3: Transmission electron photomicrograph of eye of the control black rat, rattus rattus, showing the normal structure of rods and cones. Note the fully packed and healthy nucleus (N) and the cone of the inner segment (CIS). Note also a dark and tightly packed lamellar structure of the cone and rod outer segments (COS \& ROS). (X. 2700).

\section{Exposed group:}

Scanning Electron microscopy (SEM):

Most of the general pathological changes were firstly observed in the photoreceptors of the central retina

in the exposed group. 
At age 8 months (after 2 months of exposure), the changes in this group were firstly observed as spacing between the photoreceptors 3 , shortening, disconnection between some of them and swelling of their inner segment (CIS).The Muller fibers showing thickening and hypertrophy $(\rightarrow)$ (Fig.4). Mild degeneration or rupture of some rods and cones was observed (Fig.5). The aforementioned changes have been increased gradually and observed obviously at age 10 months (after 4 months of exposure). Perforated appearance and degeneration or rupture of some scattered rods and cones segments were noted (Fig.6).
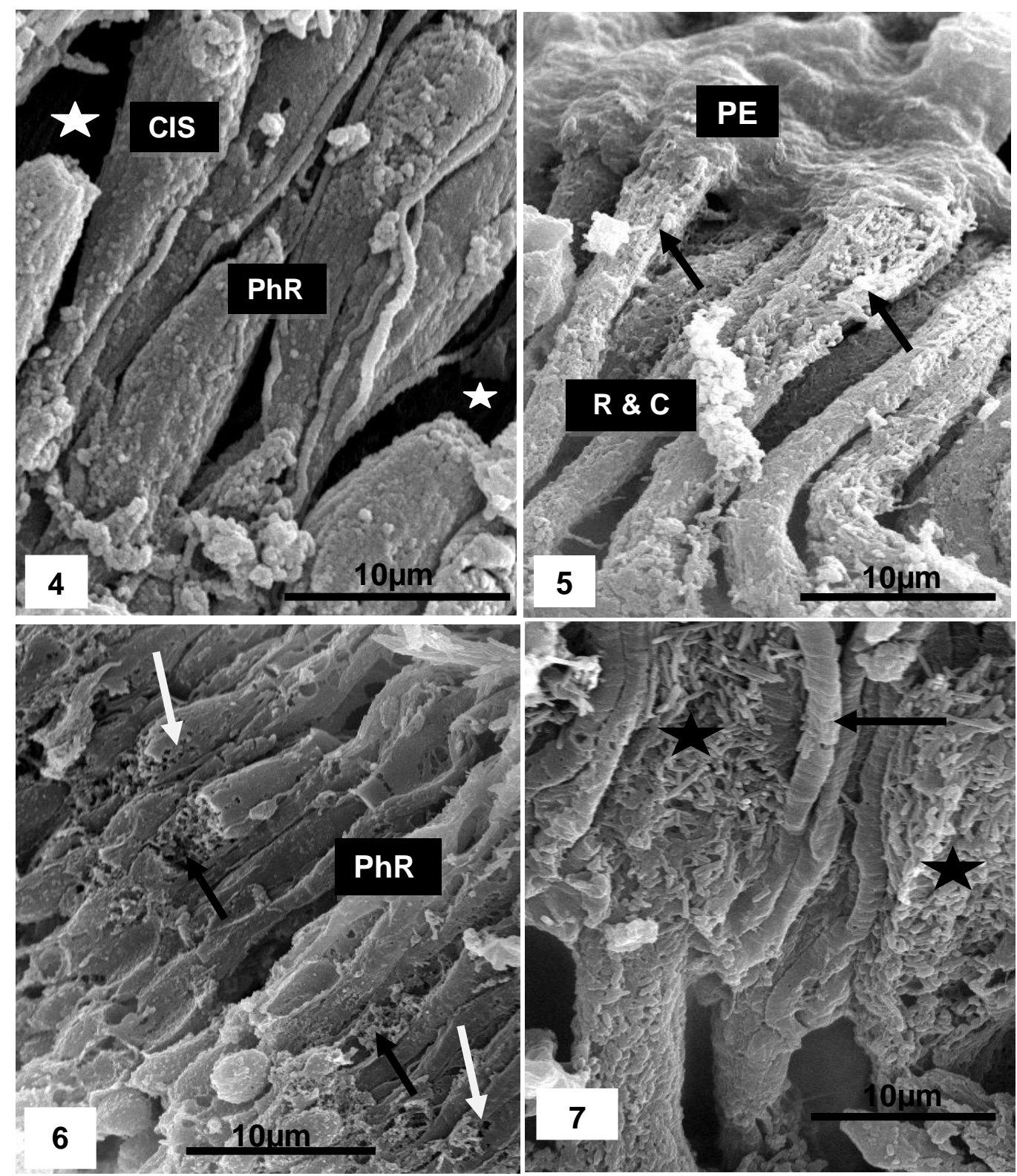

At age 12 months (after 6 months of exposure), general disorganization, great deformity, loss of the normal architecture, wider spacing between the photoreceptors and reduction of rods and cones outer segments (OS), as well as severe reduction in number of photoreceptors were the main signs after this period. Severe damages were predominant to many cones with exposed rodlets of rhodopsin (Figs.7 - 11). 
Figs. 4-6: Scanning electron photomicrograph of 2 and 4 months exposed group, showing structural changes in the retinal photoreceptor layer.

Fig. 4: Showing spacing between the photoreceptors PhR ${ }^{2}$ ), disconnection and swelling of the cone inner segment (CIS).

Fig. 5: Showing mild degeneration or rupture of some rods $\mathrm{R}$ and cones $\mathrm{C}$ (arrows).

Fig. 6: Showing structural damage in the photoreceptors $(\mathrm{PhR})$ of rat's eye after 4 months of exposure. Notice pits appearance (white arrows) and degeneration and rupture (black arrows) of some scattered rods and cones segments.

Figs. 7-13: Scanning electron photomicrograph of the 6 months exposed group, showing severe

structural damage in the retinal photoreceptor layer.
Fig. 7: Showing disorganization, perforated rod (arrow) and rupture (
s $)$ of some cones segments
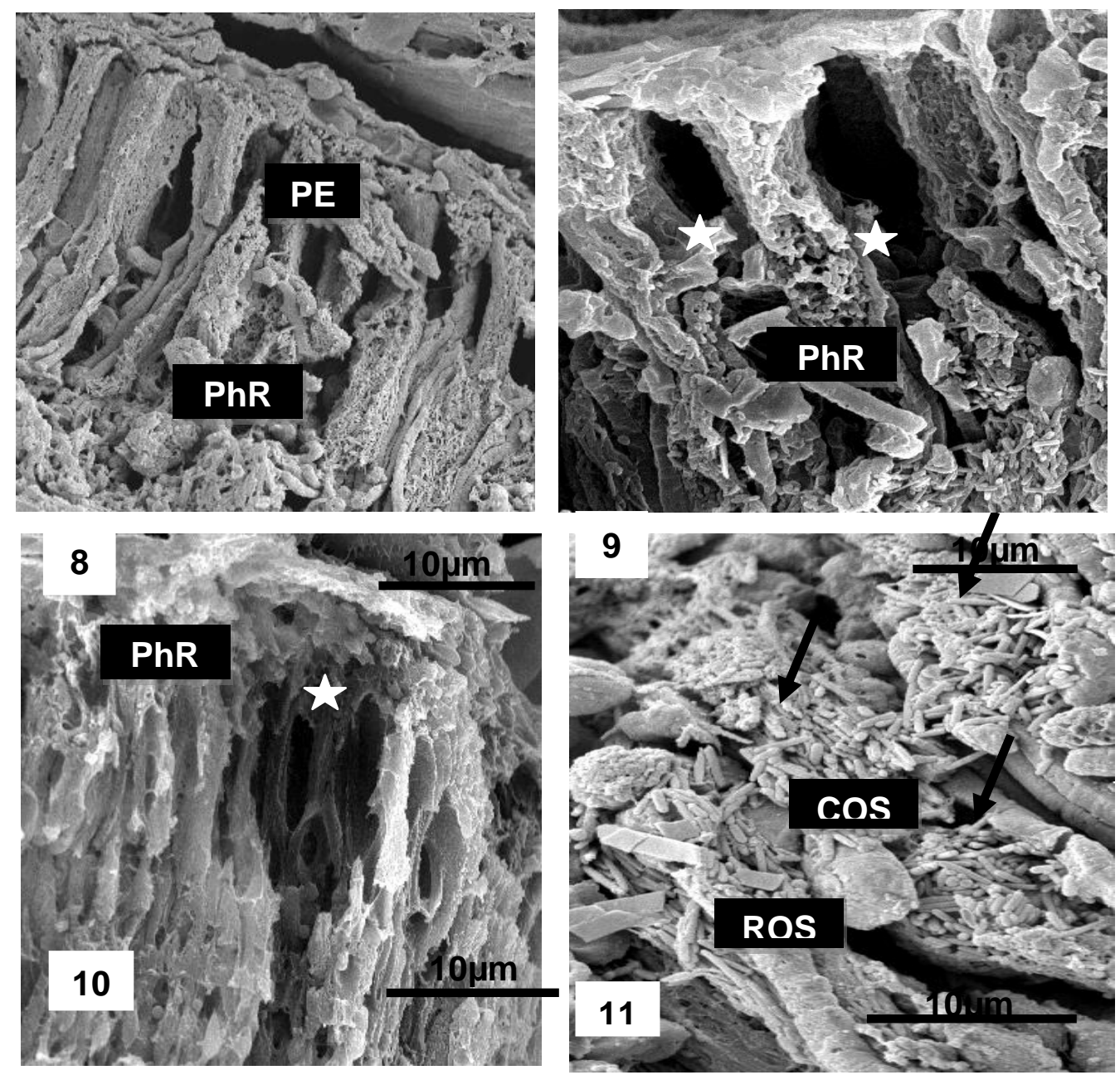

Fig. 8: Showing disorganization and deformity of the photoreceptors $(\mathrm{PhR})$.

Fig. 9: Showing wider spacing ( $\sum$ between the deformed photoreceptors $(\mathrm{PhR})$.

Fig. 10 : Showing ruined photoreceptors $(\mathrm{PhR})$ and destroyed outer segments of many rods and cones leaving a great space ( 3 which contained debris of damaged photoreceptors.

Fig. 11 : Showing severe destruction of many cones and rods with exposed rodlets of rhodopsin (arrows). 
It must be noted that, processes of pigmented epithelium were observed penetrate deeply to the photoreceptor layer between many OS of the photoreceptors. This penetration was gradually increases as the time of exposure increased covering many damaged area of photoreceptors (Figs. 12\&13.)
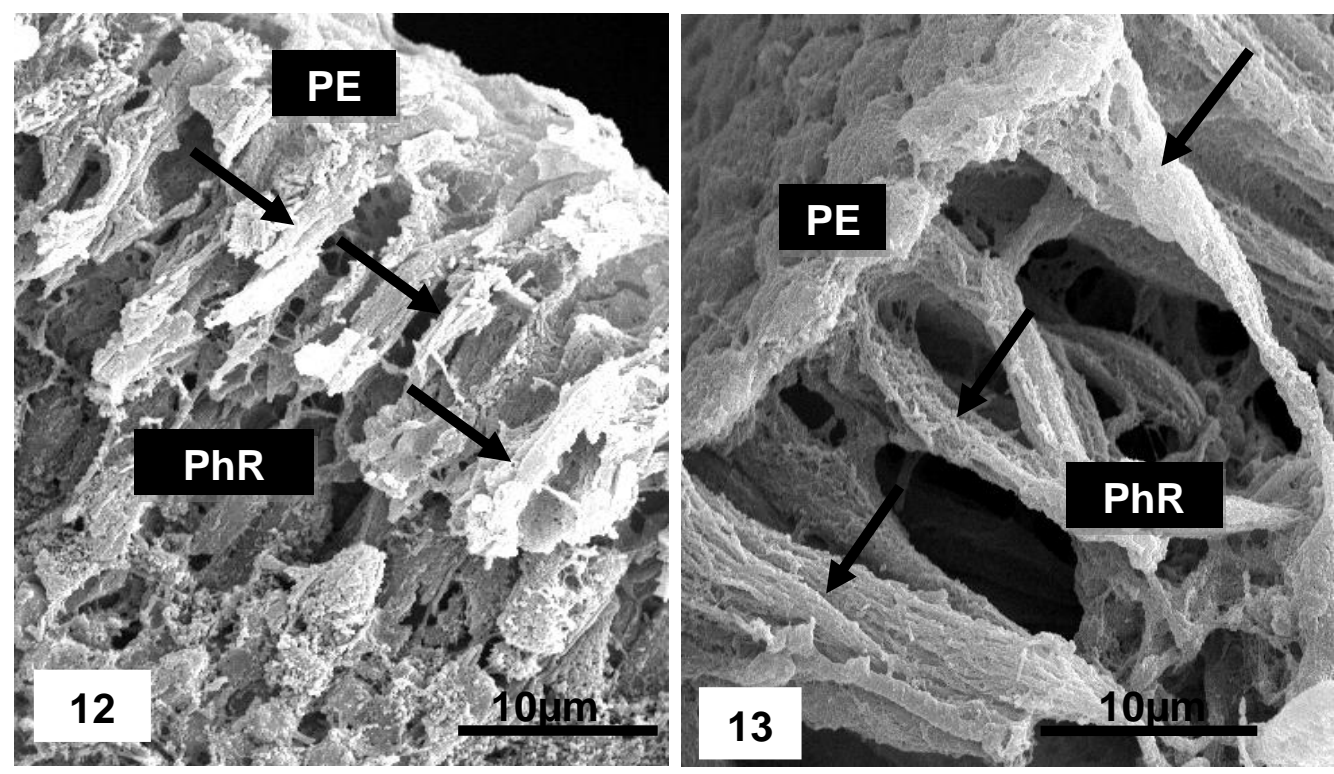

Fig. 12 : Showing processes of pigmented epithelium (arrows) between many destructed OS of the photoreceptors $(\mathrm{PhR})$.

Fig. 13 : Showing complete destructed area of photoreceptors $(\mathrm{PhR})$ penetrated deeply by extensive processes of pigmented epithelium (arrows).

\section{Transmission electron microscopy (TEM):}

After 2 months of exposure, Transmission electron microscopy showed mild effects on the lamellae of some rod and cone outer segments. These effects were represented by a slight widening of the intradiscal spaces and rupture of the plasma membrane of some ROS. The damage of some mitochondria of the RIS and CIS was also noticed (Figs. 14 \&15).

After prolonged time of exposure (4 and 6 months) a general oedema, which was represented by a large widening of the intradiscal spaces of an appreciable number of the ROS and COS was observed.
Moreover, degeneration of lamellae of some segments and complete degeneration of the core of some COS were also present. Great damage of the mitochondria of for both rod and con inner segments was also noted (Figs. 16 \&17).

A large number of low and high electron dense pigments of different sizes and shapes (rods, \& rounded) were found in between the OS of photoreceptors at different stages of exposure. However, the deformity and rupture of the processes of some PE, with their huge number of the pigments penetrate and accumulate around many highly degenerated IS were observed in the deep layers of photoreceptors after 6 months of exposure (Figs, 14, 16, 18). 

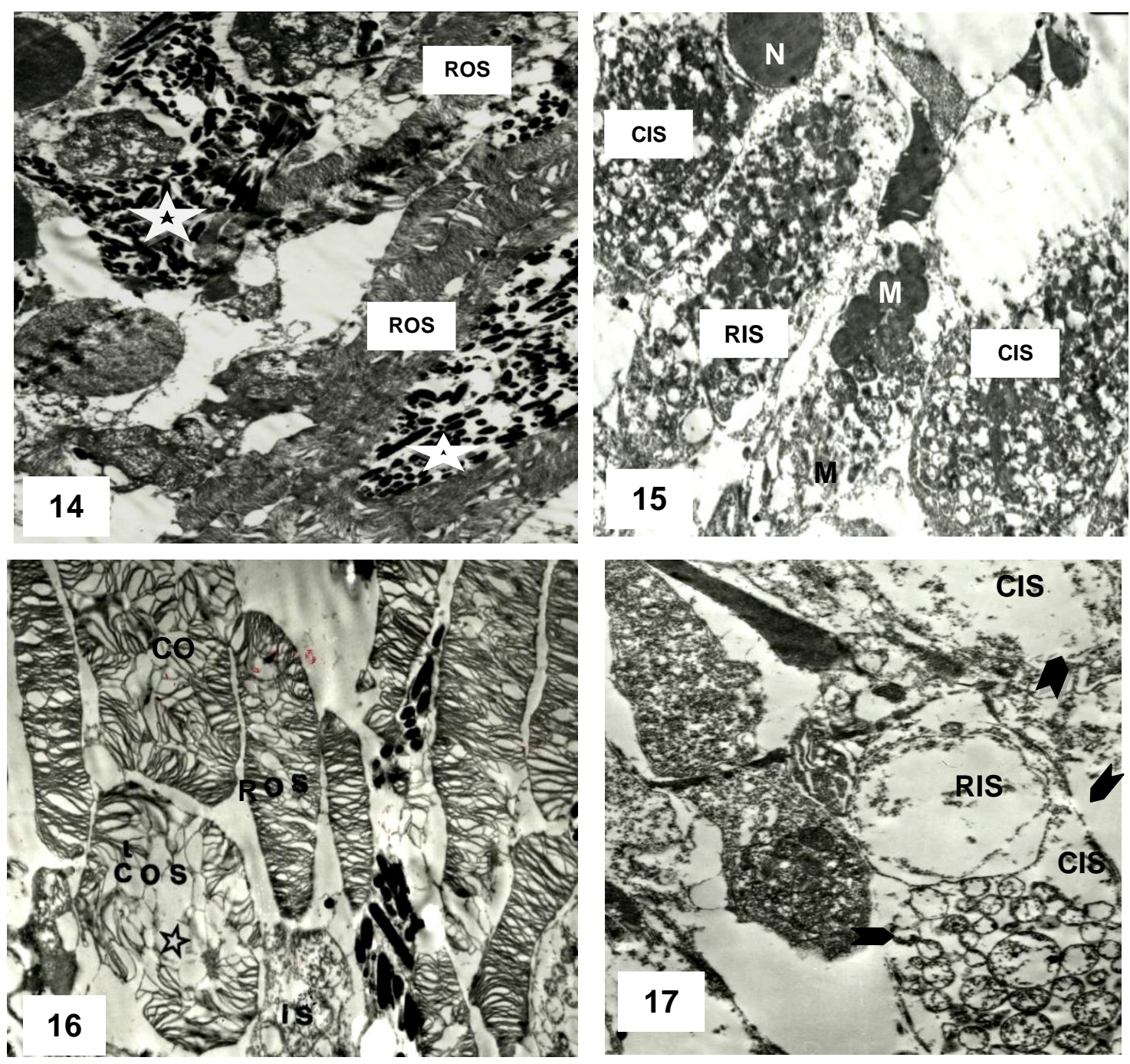

Figs. $14 \& 15$ : Transmission electron photomicrograph of eye of 2 months exposed rat, Rattus rattus, showing mild damage of the photoreceptors.

Fig. 14 : Showing a slight widening of the intradiscal spaces of the lamellae of some ROS. Note the presence of a large number of high electron dense pigments ( ). 2. 2700).

Fig. 15 : Showing some mitochondrial high electron dense, others showed ruptured cristea and outer\& inner membranes of the RIS and CIS. (X. 2700)

Fig. 16 : Transmission electron photomicrograph of eye of 4 months exposed rat, Rattus rattus, showing more widening of the intradiscal spaces of many ROS and COS. Notice swelling, vacuolation and degeneration of the core of some $\operatorname{COS}(*)$. (X. 2700)

Fig. 17 : Transmission electron photomicrograph of eye of 6 months exposed rat, Rattus rattus, showing great damage of the mitochondria of both RIS \& CIS. Note also the rupture of the outer membranes of some of these segments (arrow heads). (X. 2700). 


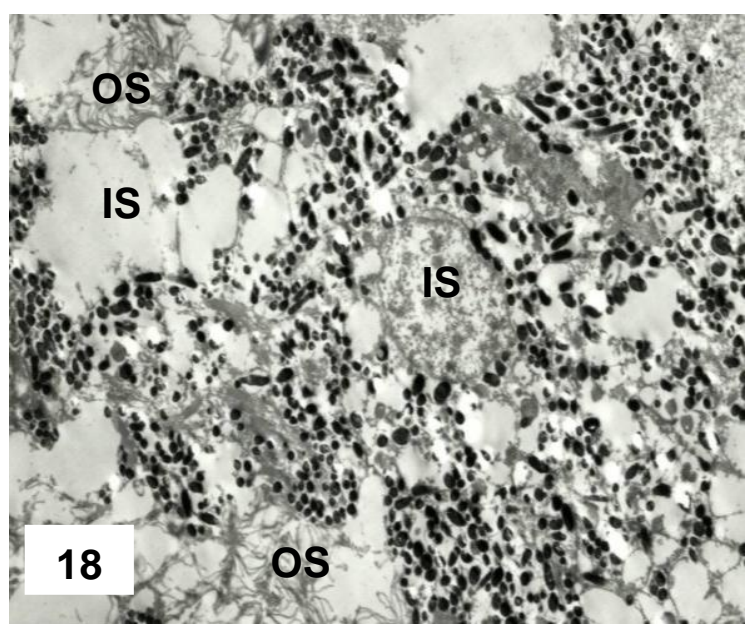

Fig. 18 : Electron photomicrograph of lead and cadmium exposed eye of rat, Rattus rattus, showing huge numbers of high electron dense pigments of varying shape and size around highly degenerated OS and IS . (X. 2700)

\section{Discussion:}

The pathological changes of the eye and the ophthalmic complications have been extensively studied from the medical point of view (Morris and Henkind, 1979; Newman et al., 1988; Wallace et al., 1992; Shimoda and Kalo, 1999; El-Dawi and Elbadry, 2001). However, little information on the human and animal eye toxicity under the effect of heavy metals is currently available and review of literature revealed the existence of sporadic studies on the visual structure of human and rat (Nir, et al., 1992; Yargicoglu et al., 1999; Roozbehi 2007; Mulak et al., 2008) he effects and complications may be attributed mainly to the toxicity of the CNS, which in turn would affect the visual system (Baatrup 1991; Kaestner and Norton, 1991; Goldstein 1992). The previous investigations, however did not point out to any deleterious effect of the heavy metals on the retinal structure of animals or even the human.

The results of retinal toxicity with lead and cadmium in this study indicate that the general pathological changes were firstly reflected on the photoreceptors of the central retina, and then directed towards the periphery. The spatial pattern of degeneration (central to peripheral progression) demonstrates similar pathological changes to the age-related progression of macular degeneration (Ulshafer et al., 1983). Also, the changes that were represented by increased spacing between OS and IS of photoreceptor, as well as disconnection and degeneration associated with the decreased numbers of ROS and COS, were similar to the first symptoms of retinal toxicity previously described under the effect of sex-linked retinitis (Szamier et al., 1979), fluorescent light (Sykes et al., 1981), in case of hereditary blindness (Ulshafer and Allen, 1984), chronic methyl alcohol (Abdel khalek et al.,1991), sodium barbiturate (Swelim and Sakr, 2001), different heavy metals (El-Dawi and Elbadry, 2001; Roozbehi 2007) in humans and different animals.

The heavy metals-induced structural damage observed in the present study was confirmed at the ultra-structural level. The disorganization, shortening, swelling, widening of the intradiscal spaces and degeneration of the lamellae of the photoreceptors OS were observed, followed by the damage of mitochondria of their IS. Similar observations have been described by Ulshafer et al., (1983) in hereditary retinal degeneration, El-Dawi and Elbadry (2001) in exposure to heavy metals and 
Swelim and Sakr (2001) in treatment with sodium barbiturate. Sykes et al., (1981) observed that in monkeys the beginning of the damage induced by extended exposure to light of fluorescent lamps is firstly exhibited in the OS, whose rods distal and cones proximal ends of $\mathrm{R}$ and $\mathrm{C}$ were swollen and disoriented. These authors noticed that the disc membranes of the outer segments were separated, often breaking up to form small tubules or vesicles. The prolonged exposure to light resulted in progressive degeneration of whole COS then ROS. Likewise, it has been found in the present study, that the whole ROS and COS were affected, but the COS were more affected. This indicates that the impairment caused by heavy metals was more prominent and had affected the whole OS at one time not distally or proximally. The effects of lead-cadmium exposure in this study resulted in rupture of the outer membrane of the OS, and complete degeneration of the core of several OS. Such findings were confirmed at the level of TEM (EI-Dawi and Elbadry, 2001), who reported the form of a pits appearance and empty core of the OS of some photoreceptors. Kalariya et al., (2009) determined the cytotoxic effects of cadmium on human retinal pigment epithelial (RPE) cells. They proved that cadmium accumulated in human body organs including retina and is particularly higher in retinal tissues of age-related macular degeneration (AMD) eyes compared to non-AMD eyes. They added that elevated reactive oxygen species (ROS) could be associated with cadmium -induced RPE cell apoptosis, one of the major contributing factors in AMD. The toxic effects of cadmium on RPE indicate that environmental heavy metals such as cadmium could be important potential factors in RPE cells death associated with some retinal diseases particularly related to smoking. Also, Kalariya et al., (2010) used in vitro cell culture model and investigated the effects of cadmium on human lens epithelial cells (HLECs) (HLE-B3). They observed cadmium-induced dose- as well as time-dependent decline in HLECs viability which was exacerbated significantly upon reduction of intracellular glutathione levels by buthionine sulfoximine (BSO). There was a dose-dependent significant increase in lactate dehydrogenase (LDH) release from HLECs suggesting cadmium-induced alteration of membrane integrity as well as necrotic cell death.

The differences between the effects of lead and cadmium on the OS may be attributed to the underlying route, though each metal causes its prospective cell injury. The effects of cadmium are generally similar to those of lead. However, saturating concentrations of cadmium depress the rod response to a greater degree than lead and the cadmium effects are not as readily reversible as the effects of lead at the higher concentrations. Cones are much more sensitive to cadmium than they are to lead and cadmium always enhances cone response amplitude. The results of the experiments in which lead and cadmium were both added to the retinal perfusate indicated that cadmium and lead both affect the same sensitive site or sites responsible for generating the rod response, but that cadmium affects an additional site that is not sensitive to lead (Sillman et al., 1982). Also, Erie et al., 2005 measured the concentration of toxic heavy metals in the fluids and tissues of human autopsy eyes. They found that Lead \& cadmium accumulate in human ocular tissues, particularly in the retinal pigments epithelium and choroid. Lead effect might have been preceded indirectly through changing parameters related to the cell environment, such as the metabolism or the oxygen supply. On the other hand, cadmium might have had a direct effect on the cell constituents, so more degeneration and complete loss of the core of many of OS were observed. Kaestner and Norton (1991) stated that a toxic substance such as organophosphrous insecticides may act directly on cell components or indirectly by changing the surrounding medium. Mulak et al. (2008) studied the relationship between chronic occupational exposure to heavy metals and eyesight. They found that the mean blood cadmium and lead levels were higher in occupationally exposed 
workers. In these workers lenticular changes were observed more often and were more intense (cortical opacities and or posterior subcapsular cataract). Also, fundus changes were of low degree and coexisting diseases may have promoted their progression. They added that field of vision changes noticed in 3 workers may have been caused by lead toxicity to optic nerve. Periodical conjuctival inflammatory states were caused by irritative dust and smoke.

The pathogenesis of lead neuropathy including vascular dysfunction, neuronal necrosis, endoneural oedema and ischemia may be responsible for this condition (Sykes et al., 1981; Kaestner and Norton, 1991). Vinores et al. (1989) reported that to understand the mechanism by which the toxic substances could affect the various retinal structures, we have to consider that normal retinal function requires a rigid control of extracellular fluid and ion concentrations, which are accomplished through specialized structural and metabolic features of the retinal capillary endothelium and retinal pigment epithelium. This has led to the concept of the blood-retinal barrier (BRB). Swelim and Sakr (2001) postulated that the breakdown or damage to the components of the $\mathrm{BRB}$ is responsible for the alterations that may happen to the layers of retina as a consequence of drug effect. Other investigators explained that the metal toxicity depends upon the calcium-channel system of the plasma membrane. Also, Goldstein (1992) found that lead interacted with calcium-dependent systems in different ways. Most probably, lead has a greater capacity, more than cadmium in denaturating lipid and protein molecules of the plasma membrane resulting in its rupture.

Green et al. (1994) reported that high cadmium concentrations increased the permeability of the rabbit corneal endothelium, leading to corneal swelling. The aforementioned studies supported what it has been found in the present work, since degeneration of the core of the OS occurred, without disruption of the plasma membrane.
The problem of metal toxicity becomes more complex, owing to successive exposure of the organs to different physical, chemical, biological and psychological factors in the environment. In the present investigation, the impact of lead and cadmium caused more progressive changes than that could be caused by each one of them separately. Mulak et al. (2008) stated that in humans, the most common and dangerous forms of the eye intoxication are caused by lead additionally reinforced by cadmium.

In the present investigation, the mechanism of interaction between the two metals to produce retinal pathogenesis, is still vague and unknown, which requires additional efforts to through more light on this issue. In this study, the processes of the PE filled with different shapes and sizes of either faintly or darkly stained granules (pigments) were observed between some of the damaged OS and IS of the photoreceptors after lead-cadmium exposure. In case of inherited retinal degeneration, LaVail et al. (1972) stated that there was increased cellular debris in the sub-retinal space of affected rats, and some PE cells may detach to scavenge and clean up the debris which has been shown to be toxic to photoreceptors. Moreover, prolonged exposure of monkeys to light results in the involvement of the pigment epithelium in the degenerative processes (Sykes et al., 1981). Ulshafer and Allen (1984) concluded that it is unknown if degeneration of the $\mathrm{PE}$ is a direct expression of a secondary phenomenon that arises in response to degeneration of the photoreceptors. Swelim and Sakr (2001) reported that the pigment epithelial cells, suffered from great distortion and various forms of damage under the effect of sodium barbiturate. The aforementioned studies, are in agreement with what has been found in the present investigation, where excessive extension of the PE processes to the deep layer of the photoreceptors and accumulation of a huge number of pigments around some highly degenerated OS and IS of the photoreceptors after prolonged exposure to lead-cadmium fumes. Most probably, such action is an adaptive 
mechanism to scavenge the degenerated segments and consequently to protect the photoreceptors.

In conclusion, the extent and implications of the impairment of the retinal structure under the effect of heavy metals for long periods need further studies to reevaluate and reconsider the international permissible levels of these metals and to be aware of their passive impacts on the retinal structure and visual acuity.

\section{References:}

Abdel khaliek L R, El-Sayed N K, Gaafar K M and Karam S H (1991): Histoenzyme changes in chronic methyl alcohol retinotoxicity in rats. Egyp, J. Histol., 14 (2):377 - 384.

Ali $M A$ and Klyue $M$ (1985): Vision in Vertebrates. New York, Plenum press.

Allen P (1995): Accumulation profiles of lead and cadmium in the edible tissues of Oreochromis aureus during acute exposure. J. Fish Biol., 47: 559-569.

Andrew W and Hickman C P (1974): Histology of the Vertebrates: A Comparative Text, C.V. Mosby Company, Saint Louis.

APHA (American Public Health Association Standard Methods) Amereican Water Works Association and Water Pollution Control Federation (1985): Standard Methods for the Examination of Water and Waste Water, $16^{\text {th }}$ ed., Washington, D.C.

Baatrup E (1991): Structural and functional effect of heavy metals on the nervous system, including sense organs of fish. Comparative Biochemistry and Physiology Part C: Comparative Pharmacology. Volume 100, issues1-2 pages 253-257.

Bano $Y$ and Hasan $M$ (1990): Histopathological lesions in the body organs of catfish Heteropneustes fossilis following mercury intoxication. J. Environ. Sci. Health, (B) 25(1): $67-85$.

Burnside B and Ackland N (1983): Effect of circadian rythm and CAMP on retinomotor movements in the green sunfish, Lepomis. Inves. Ophthal. Vis. Sci., 25(5): 539-545.

El-Dawi E F A (2004): A comparative scanning electron microscopic study on the impact of lead and cadmium exposure on the corneal epithelium of the surface and bottom teleosts. J. Egyp. Acad. Soc. Environ. Develop. 5 (2): 171 $-194$.

El-Dawi $E$ F A and Elbadry $M$ (2001): Retinotoxicity and photoreceptors ultrastructural alterations in the arabian killifish, aphanius dispar exposed to lead and cadmium. J. Egyp. Acad. Soc. Environ. Develop. (D- Environ. Studies), 2 (4): 73 - 103.

Elgamal M I and Hassanien M A (2007): Evaluation of semen quality among traffic policemen and battery workers exposed to lead. J. Union Arab Biol. Cairo. 12 (A). Zoology: 123-142.

Erie J C, Butz J A, Good J A, Erie E A, Burritt $M$ F and Cameron J D (2005): Heavy metal concentrations in human eyes. Am. J. Ophthalmol., 139 (5):888-893.

Gerhardsson $L$ and Skerfving $S$ (1996): Concepts on biological markers and biomonitoring for metal toxicity. In: "Toxicology of Metals". Change L, Mogos L, Suzuki T, Lewis Publishers, Boca Raton, New York, Tokyo.

Goldstein G W (1992): Neurologic concepts of lead poisoning in children. Pediatr. Ann., (21): $384-388$.

Green K, Cheeks L, Mull D S (1994): Effects of calcium channel blockers on rabbit corneal endothelial function. Curr. Eye Res., 13: $401-408$

Kaestner A and Norton S (1991): Nervous System. In: "Handbook of Toxicologic Pathology".Eds., Wander, M. Haschek and Collin, G. Rousseaux. Chapter Acad. Press Inc., Harcourt Brace Jovanovich, Publishers. N. York, London, Toronto. 20, pp., 625 - 674.

Kalariya N M, Nair B, Kalariya D K, Wills N K and Van Kuijk F J (2010): Cadmium-induced induction of cell death in human lens epithelial cells: implications to smoking associated cataractogenesis. Toxicol. Lett., 198(1):56-62.

Kalariya N M, Wills $\mathbf{N} \mathbf{K}$, Ramana $\mathbf{K}$ V, Srivastava S K and Van Kuijk F J (2009): Cadmium-induced apoptotic death of human retinal pigment epithelial cells is mediated by MAPK pathway. Exp. Eye Res., 89(4):494-502.

Kirsch M, Wagner $\mathbf{H} \mathbf{J}$ and Douglas $\mathbf{R} \mathbf{H}$ (1989): Rods trigger light adaptive retinomotor movements in all spectral cone types of a teleost fish. Vis. Res., 29 (4): 389-396.

LaVail M, Sidman R L and O'Neil D (1972): Photoreceptor-pigment epithelial cell relationships in rats with inherited retinal degeneration. Radioautographic and electron microscope evidence for a dual source of extralamellar material. J. Cell Biol., (13):185209.

Lockitch G (1993): Perspectives on lead toxicity. Clin. Biochem., (26): $371-381$.

Millonig G (1964): Study on the factors which influence preservation of fine structure. In: Symposium on Electron Microsopy. P.Buffa ed, 
Consiglio Nazionale delle Ricerche, Roma; p. 347.

Morris D A and Henkind $P$ (1979): Pathological responses of the human retinal pigment epithelium. In: "The Retinal Pigment Epithelium". K M Zinn and MP Marnar Eds. Harvard University Press, Cambridge, Massachusetts pp. 247-266.

Mulak M, Misiuk-Hojło M, Markuszewski B and Dembska K (2008): Influence of chronic exposure to heavy metals on eyesight. Klin Oczna, 110(4-6):176-182.

Newman N M, Duaredo D A, Ho J T, Klein J $C$ and Bimbaum N S(1988): Bilateral optic neuropathy and osteolytic sinusitis. Complications of cocaine abuse. JAMA, 259(1): 72-74.

Nir A, Tamir A, Zelnik $\mathbf{N}$ and Iancu $\mathbf{T} \mathbf{C}$ (1992): Is eye cosmetics a source of lead poisoning? Ir. J. Med. Sci., 28: 417 - 421.

Pundir R and Saxena A B (1992): Chronic toxic exposure of cadmium on the pituitary gland of fish Puntius ticto and pattern of recumbent. J. Environ. Biol., 13(1): 69-80

Roozbehi A (2007): Effects of cadmium on photoreceptors and ganglionic cells of retinal layer in mice embryo - An ultrastructural study. Indian J. Exp. Biol., 45: 469 - 474

Shimoda K and Kalo M (1999): Apoptotic photoreceptor cell death induced by quinolone phototoxicity in mice. Toxicol. Lett. Mer., 5:105(1): 9-15.

Sillman A J, Bolnick D A, Bosetti J B, Haynes L W and Walter A E (1982): The effects of lead and of cadmium on the mass photoreceptor potential: the dose-response relationship. Neurotoxicology, 3(4):179-94.

Simeonov L I and Hassanien M A (2009): Exposure and Risk Assessment of Chemical Pollution-Contemporary Methodology. Edited by L I Simeonov and M A Hassanien ISBN 978-90-481-2334-6, Springer.
Swelim H H and Sakr A A (2001): Retinal ultra-structural changes in albino mice after treatment with sodium barbiturate. J. Egypt. Acad. Soc. Environ. Develop.,(D), 2 (3):147178

Sykes S M, Robison W G, Waxler J R M and Kuwabara T (1981): Damage to the monkey retina by broad-spectrum fluorescent light. Invest. Ophthal. Vis. Sci., 20(4): 425 - 434.

Szamier R B, Berson E L, Klein R and Meyer $S$ (1979): Sex-linked retinitis pigmentosa: ultrastructure of photoreceptors and pigment epithelium. Invest. Ophthal. Vis.Sci., 18: 145156.

Ulshafer R J and Allen CE (1984): Scanning electron microscopy of the retina in an animal model of hereditary blindness. Scan.

Elec. Mic., II: 841- 848

Ulshafer, R.J., Allen, C.B. and Wolf, E.D. (1983): Hereditary retinal degeneration in Rhode IslandRed chickens:LM and EM observations.Invest. Ophthal. Vis. Sei., 20 (Suppl.):115.Abstract.

Vinores S A, Gadegbeku C, Campochiaro P $A$ and Richard G W (1989): Immunohistochemical localization of blood retinal barrier breakdown in human diabetics. Am.3.Pathol. 34(2): 231-235.

Wallace $R$ T, Brow T G C, Benson $W$ and Sivalingham A (1992): Sudden retinal manifestations of intranasal cocaine and methamphetamine abuse. Am. J. Ophthal., 774(2):158-160.

WHO (1984): Guidelines for drinking water quality. Geneva, No. III.

Yargicoglu P, Agar A, Edremithioglu M, Oguz Y and Aprydin C (1999): The effect of cadmium on visual evoked potentials in alloxane-induced diabetic rats: relation to lipid peroxidation. Acta Diabetal., 36 (4) : 197 - 204. 


\title{
التغيرات التركيبية الاقيقة لمستقبلات الضوء فى الجرذ الأسود، راتس راتس المعرضة لمعادن ثقيلة معينة
}

\author{
السيد فكرى على الضوى 1 و نعيمه ابراهيم نجيب2

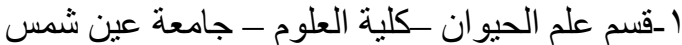 \\ rا_قسم البحوث الصحية الإثعاعية -المركز القومى لبحوث و تكنولوجيا الإثعاع - هيئة الطاقة الذرية
}

يتناول هذا البحث دراسة التأثيرات السُبية لإثنين من المعادن الثقيلة، هما الرصاص والكادميوم على شبكية العين للجرذ الأسود (راتس راتس) لددة ץ ، ؛ ، ، أثـهـر وذللك باستخام الميكروسكوب الإكترونى الماسح و والناقن.

وقد أوضحت النتائج بإستذام الميكروسكوب الإكترونى الماسح أن مستقبلات الضوء من أكثر مكونات الثبكية تأثرا فى فترات التعرض المختلفة، وقد انعكس ذلك فى التفكك وزيادة الفراغات بين مكوناتها من العصى و المخاريط و قصر و انتفاخ مسقبلات الضوء ، وكان ذلك أكثر وضوحا بعد 1 أثهر من التعرض. وقا أكلت النتائج بإستخذام الميكروسكوب الإكترونى الناقذ حدوث تحلل للصفائح الاخلية للعقل الخارجية

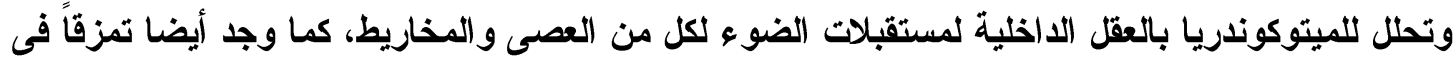
الغشاء البلازمى للعقل الخارجية من العصى و المخاريط. وقد لوحظ زيادة التأثير على مستقبلات الضوء بزيادة فترة التعرض وكان ذلك مصحوبا بتظلغ حبيبات صبغية كثيرة، مختلفة الأثكال والأحجام بين العقل الخارجية للعصى و المخاريط لمسقبلات الضوء، وز اد ذلك التظلغل إلى العقل الاذاخلية المتحللة للعصى و المخاريط بعد 1 أثهر من التجربة.

ويستتج من هذا البحث أن شبكية العين قـ تأثرت بالرصاص و الكادميوم حتى بعد شهرين من التعرض للملوثات. مما يشير إلى خطورة وجود الإسسان فى مثل هذه البيئة الملوثة بتلك المعادن على المدى البعدي. 